\title{
ASSESSMENT OF LAND USE CHANGE SCENARIO TO INCREASE PRIMARY PRODUCTIVITY FUNCTION AT LOCAL SCALE
}

\author{
Kristine Valujeva ${ }^{1,3}$, Aleksejs Nipers ${ }^{1}$, Ainars Lupikis ${ }^{2}$, Jovita Pilecka ${ }^{1}$, Rogier P.O. Schulte ${ }^{3}$ \\ ${ }^{1}$ Latvia University of Life Science and Technologies, Latvia \\ ${ }^{2}$ Latvia State Forest Research Institute 'Silava', Latvia \\ ${ }^{3}$ Wageningen University and Research, the Netherlands \\ kristine.valujeva@1lu.lv
}

\begin{abstract}
The global population has begun to rise exponentially; therefore, the demand for bioresources including food and fibre is increasing. An increasing demand for food and fibre necessitates more sustainable use of natural resources especially for soilbased ecosystem services. In this context, Functional Land Management was developed to optimize agricultural soilbased ecosystem services to meet both agricultural and environmental targets simultaneously. The aim of the research is to evaluate unmanaged agricultural land use change impact on primary productivity function in three parishes in Latvia by using Functional Land Management framework.

Evaluation of primary productivity function was accomplished for both sectors agriculture and forestry by using profit and working hours as a proxyindicators. Production of vegetables and perennial plantations have higher supply of primary productivity function comparing to other land uses.

Land use changes affect all soil functions that we expect from our land, especially primary productivity function. After applying land use changes, an increase in profit is higher in Liezere parish for both areas on mineral soils (7.1\%) and areas on organic soils (5.2\%); while an increase in working hours is higher in Usma parish: $36.6 \%$ in areas on mineral soils and $1.0 \%$ increase in areas on organic soils.

Shortterm benefits are received from agricultural land, while forest land provides long-term return which increases over time but can only be obtained after reaching the age of felling. Before applying land use changes or changes in management practices we have to consider other soil function and national commitments.
\end{abstract}

Key words: Functional Land Management, soil functions, agricultural land, forestry land, policy, production.

\section{Introduction}

The global population has begun to rise exponentially. In 2017, there were 7.6 billion people. The latest forecast shows that the world population will exceed 8.5 billion people by 2030 and 9.7 billion by 2050 (UN, 2017). This increases the demand for bioresources including food and fibre. This, in turn, necessitates more sustainable use of natural resources especially for soil-based ecosystem services.

Soil basically is non-renewable resource and provides many ecological and social functions (Mueller et al., 2010) and the key soil function 'food and biomass production' must be maintained sustainably (Blum, 1993). Therefore, the EU has established a framework for the protection of soil and the preservation of its capacity to perform environmental, socio-economic and cultural functions, namely biomass production, nutrient and water storage, filtering and transformation, carbon sequestration, the provision of a biodiversity pool, as well as a physical and cultural environment for humans, a source of raw materials and an archive of geological and archaeological heritage (EC, 2006).

In this context, multifunctional soil-based framework, called Functional Land Management (FLM), is developed to quantify the supply and demand of five soil functions, such as primary productivity, carbon sequestration and regulation, water purification and regulation, the provision and cycling of nutrients, and the provision of habitats for biodiversity (Schulte et al., 2014). Framework aims to optimize agricultural soil-based ecosystem services to meet both agricultural and environmental targets simultaneously. The performance of each soil function depends on land use and soil properties (Coyle et al., 2016). Coyle et al., (2016) expanded FLM framework by developing conceptual models for assessment of supply of each soil function, including the interrelation of land use and dominant soil property. In Ireland, wetness is the dominant soil property. Using results of conceptual models, soil matrix was created. Those soil matric can be used to show changes in suite of soil functions after implementations of various policy measures. Further framework was used to explore different scenarios for meeting agronomic and environmental objectives simultaneously (Valujeva et al., 2016).

In Latvia, bioresources have a pivotal role to provide economic growth; therefore, Latvian Bioeconomy Strategy until 2030 was developed (LIBRA2030, 2017). One of the main opportunities for development of economy in Latvia is sustainable and efficient use of natural resources. Sustainable development of traditional bioeconomy sectors includes social, economic and environmental dimensions and also requires sustainable soil management. There are three main targets for development of traditional bioeconomy sectors, namely agriculture and forestry: 
1. To increase a value added from agriculture and forestry sectors from EUR 2.33 billion in 2016 to EUR 3.8 billion in 2030;

2. To increase a value of bioeconomy production exports from EUR 4.26 billion in 2016 to at least EUR 9 billion in 2030;

3. To provide employment for at least 128,000 inhabitants.

Current research is limited to primary productivity function. The aim of the research is to evaluate unmanaged agricultural land use change impact on primary productivity function in three parishes in Latvia by using Functional Land Management framework. The main tasks of the research are 1) to quantify supply and demand of primary productivity function in three parishes in Latvia; 2) to identify possible pathways how to improve performance of primary productivity function. The object of the study is agricultural and forestry land in Latvia.

\section{Materials and Methods \\ FLM in Latvia}

FLM framework was adapted for Latvia. Data of agricultural land use and farming systems from the State Land Service, the Rural Support Service, Agricultural Data Centre, data of soil type and properties from digitized historical soil maps and land reclamation, and data of forest from the State Forest Service were collected within the project 'Evaluation of the land use optimization opportunities within the Latvian climate policy framework' (Nipers, 2019). Data collected within project was used to create land use and dominant soil property matrix by Valujeva et al., (in preparation). The land use of Latvia was divided into agricultural land and forestry land. Agricultural land had subdivisions, such as grain, oilseed, pulses (GOP), vegetables, perennial plantations, other crops, no crops, grasslands, not cultivated agricultural land and overgrown agricultural land, while forestry land had been divided into managed coniferous forests and managed deciduous forests, and natural coniferous forests and natural deciduous forests. In Latvia, management of organic soils is responsible for $50 \%$ of direct N2O emissions (NIR, 2018); therefore, the carbon content in soil was chosen as the main characteristic for soil properties.

Methodology for quantification of supply of and demand for primary productivity function

Within the project evaluation of socio-economic impact was accomplished for both sectors agriculture and forestry. Proxy-indicator for economic component was profit, but for social component - working hours. Profit for agriculture was a function of sold products, direct payments, and production costs including amortisation, while for forestry appreciation instead of profit was used. Average data of period 2014-
2016 was used for determining profit per hectare. Appreciation per year was a multiplication of stock growth per year and a profit per $\mathrm{m} 3$ of wood in the end of production cycle. Workplaces were evaluated as a necessary hourly labour input per hectare per year for both agriculture and forestry. Profit and working hours were set per hectare. Methodology for quantification of profit and working hours were adapted for land use and soil property by Valujeva et al., (in preparation). Tabular index approach developed by Greiner et al., (2018) was used to create indicator from two indexes (profit and working hours) Valujeva et al., (in preparation). Gradient of 5 classes where 1 is low and 10 is high was used for mapping. In the study, quantification of supply of primary productivity function was done in polygon level for three parishes in Latvia.

Demand for primary productivity function is framed by regional and national planning documents, namely Development Programme of Kurzeme Planning Region for 2014-2020; Development Programme of Zemgale Planning Region for 20142020; Development Programme of Vidzeme Planning Region for 2014-2020; Latvia Bioeconomy Strategy 2030; National Development Plan of Latvia for 2014-2020; Sustainable Development Strategy of Latvia until 2030. Calculation of demand for each municipality in accordance to targets framed by Bioeconomy Strategy are accomplished by Valujeva et al., (in preparation). Indicator was created from target for value added from agriculture and forestry sectors and unemployment rate (Valujeva et al., in preparation).

\section{Case studies}

In the study, the methodology developed by (Nipers, 2019) and expanded by (Valujeva et al., in preparation) was used to quantify the supply and demand in three different parishes of Latvia, namely Usma, Zalenieki, Liezere. Distribution of land uses in relation to soil carbon content for each parish was shown in Table 1. Usma parish is located in NorthWest part of Latvia in Ventspils municipality; the land area is $219.35 \mathrm{~km}^{2}$, population was 527 inhabitants and unemployment rate was $5.7 \%$ (SRDA, 2016) in 2018. In Usma parish, $62 \%$ of total area is covered by forests, $7 \%$ of total area is used for agricultural purposes and $25 \%$ of agricultural land in Usma parish is not cultivated or overgrown (Table 1). In Usma, $25 \%$ of agricultural and forestry land is located on organic soils. Zalenieki parish is located in Jelgava municipality; the land area is $122.16 \mathrm{~km}^{2}$, population was 1,486 inhabitants and unemployment rate was $3.9 \%$ (SRDA, 2016) in 2018. The main land use in Zalenieki parish is agricultural land which covers $71 \%$ of total area and $0.6 \%$ of agricultural land is not cultivated or overgrown, but only $14 \%$ of total area 
Areas of land use in Usma, Zalenieki, Liezere parishes

\begin{tabular}{|l|c|c|c|c|c|c|}
\hline \multirow{2}{*}{\multicolumn{2}{|c}{ Land use }} & \multicolumn{2}{|c|}{ Usma parish, ha } & Zalenieki parish, ha & \multicolumn{2}{c|}{ Liezere parish, ha } \\
\cline { 2 - 7 } & $\begin{array}{c}\text { Mineral } \\
\text { soil }\end{array}$ & $\begin{array}{c}\text { Organic } \\
\text { soil }\end{array}$ & $\begin{array}{c}\text { Mineral } \\
\text { soil }\end{array}$ & $\begin{array}{c}\text { Organic } \\
\text { soil }\end{array}$ & $\begin{array}{c}\text { Mineral } \\
\text { soil }\end{array}$ & $\begin{array}{c}\text { Organic } \\
\text { soil }\end{array}$ \\
\hline GOP & 131.0 & 9.4 & $7,514.0$ & 0.1 & 490.0 & 66.8 \\
\hline Vegetables & 6.0 & 0.0 & 80.0 & 0 & 1.0 & 0 \\
\hline Perennial plantations & 1.0 & 0 & 26.0 & 0 & 13.0 & 0 \\
\hline Other crops & 172.0 & 18.0 & 766.0 & 0 & $1,110.0$ & 138.0 \\
\hline No crops & 280.7 & 44.9 & 209.4 & 0 & 659.1 & 228.2 \\
\hline Grassland & 371.0 & 54.0 & 54.0 & 1.0 & $2,147.0$ & 287.0 \\
\hline Not cultivated agricultural land & 242.0 & 70.0 & 42.0 & 0 & 218.0 & 49.0 \\
\hline Overgrown agricultural land & 42.0 & 17.0 & 8.0 & 0 & 583.0 & 84.0 \\
\hline Managed coniferous forest & $7,315.0$ & $1,945.5$ & 551.99 & 33.4 & $3,666.8$ & 954.38 \\
\hline Managed deciduous forest & $1,133.2$ & $1,027.6$ & 901.8 & 152.9 & 7,000 & $1,807.2$ \\
\hline Natural coniferous forest & $1,187.2$ & 481.1 & 63.7 & 0 & 8.6 & 0 \\
\hline Natural deciduous forest & 258.0 & 135.0 & 26.5 & 0.3 & 4.0 & 0 \\
\hline & $11,139.1$ & $3,802.5$ & $10,243.39$ & 187.7 & $15,900.5$ & $3,614.58$ \\
\hline
\end{tabular}

Source: authors' calculations based on Nipers, (2019).

is covered by forests (Table 1). In Zalenieki, $2 \%$ of agricultural and forestry land is located on organic soils. Liezere parish is located in North-East part of Latvia in Madona municipality; the land area is $254.70 \mathrm{~km}^{2}$, population was 1,285 inhabitants and unemployment rate was $7.20 \%$ (SRDA, 2016) in 2018. 53\% of total area in Liezere parish is covered by forests, $24 \%$ is agricultural land and $15 \%$ of agricultural land is not cultivated or overgrown (Table 1). In Liezere, $19 \%$ of agricultural and forestry land is located on organic soils.

Scenarios

In the study, the land use change scenario impact on primary productivity function was explored. The land use changes included the return of not cultivated and overgrown agricultural land to agricultural production depending on soil quality rate: soil quality points less than 25 means that it is more suitable for forestry; soils with a quality rate in the range between 25 and 38 points is suitable for grass production; soil with quality points in the range from 38 to 77 is suitable for crop production. The scenario included the following land use changes: 1) the land use change from not cultivated and overgrown areas on mineral soils with soil quality points less than 25 to managed coniferous forests on mineral soils; 2) the land use changes from not cultivated and overgrown areas on organic soils to managed coniferous forests on organic soils; 3 ) the land use changes from not cultivated and overgrown areas on mineral soils with soil quality points in the range from 25 to 38 to grassland on mineral soil; 4) not cultivated and overgrown areas with soil quality points in the range from 38 to 77 on mineral soils were equally distributed between GOP, vegetables, perennial plantations, and other crops on mineral soils.

\section{Results and Discussion}

National demand for primary productivity in Latvia is framed by Latvia Bioeconomy Strategy 2030. There is no demand at municipality level, but Valujeva et al., (in preparation) has divided national target into regional targets depending on regional GDP target, share of agriculture, forestry, fisheries and unemployment rate at municipality level. The demand for primary productivity function is higher in Usma and Zalenieki, but lower in Liezere.

Supply of primary productivity function, with proxy-indicators profit and working hours, strongly relates to the land use and soil class. A higher supply of primary productivity function is in Zalenieki parish, while the supply of primary productivity function in Usma and Liezere parishes is distribution between low and high supply (Figure 1). Areas with low supply are not cultivated and overgrown agricultural land, and no crop areas which means that those areas are not used to produce goods for market or there is no available information. Total area with low supply of primary productivity function in Usma is $2,662 \mathrm{ha}$, in Zalenieki 270 ha, but in Liezere 3,054 ha.

Table 2 shows that GOP and vegetables grown on mineral soils have higher profits in Zalenieki compared to Usma and Liezere. Comparing perennial plantations on mineral soils in all parishes: the profit in Zalenieki is EUR 75,400 per year, which is 50\% more than in Liezere and 26 times more than in Usma. Profit from other crops is the highest in Liezere, where it 


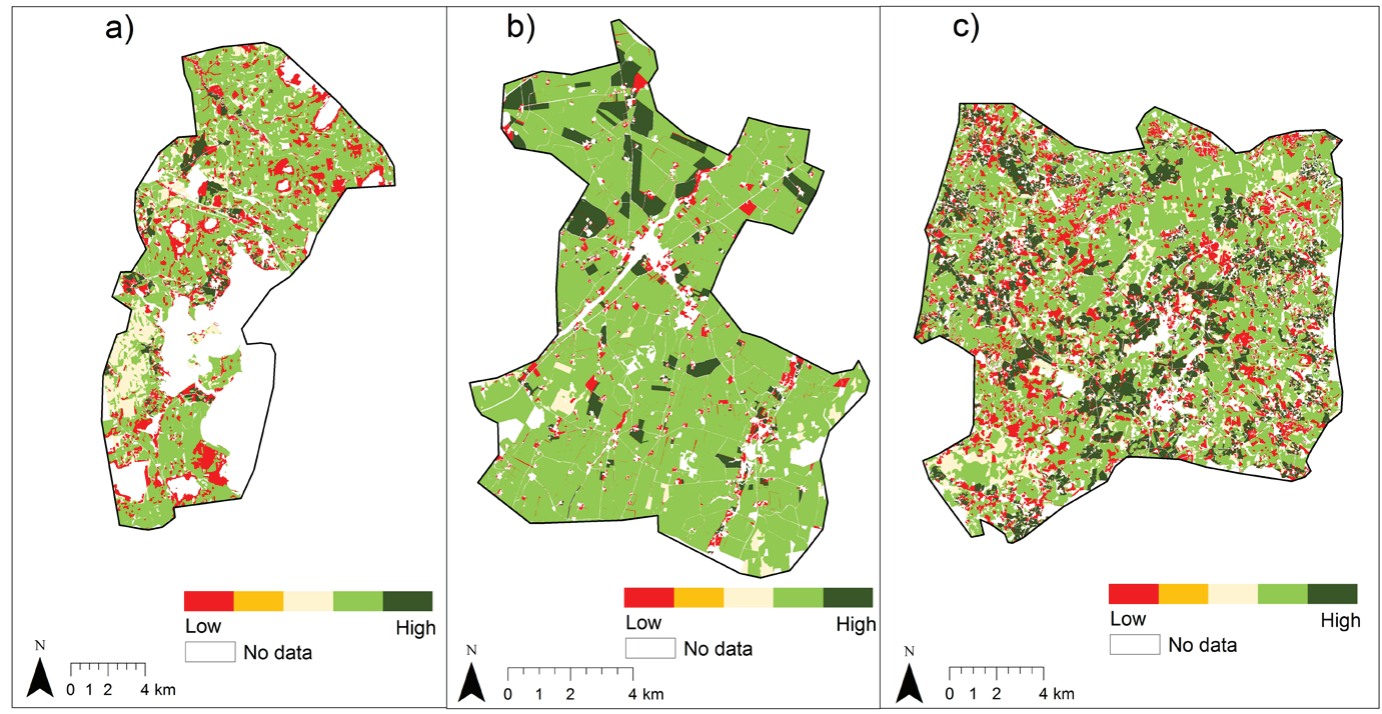

Figure 1. Supply of primary productivity function: a) Usma parish;

b) Zalenieki parish; c) Liezere parish.

Source: authors' construction based on Nipers, (2019) and Valujeva et al., (in preparation).

reaches EUR 333,000 per year, while in Zalenieki the profit is almost EUR 300,000 per year, but in Usma the profit is about 6.4 times smaller than in Liezere.

The highest profit in managed coniferous forests is observed in the parish, where the forest canopy predominates: the profit in Usma is EUR 1,975,050 per year which exceeds the profit in Liezere by almost one million and which is 13 times more than in Zalenieki where the agricultural land predominates. In managed decidious forest, higher profit is observed in Liezere (EUR 1,050,000 per year), while in other parishes the profit exceeds EUR 100,000 per year. Natural coniferous forests have the highest profit in Usma: the profit is reaching EUR 160,272 per year. The profit from natural decidious forests in Usma is EUR 19,350 per year, while in Zalenieki the profit is only EUR 133 per year, but in Liezere there are no natural decidious forests.

Table 3 shows that GOP, vegetables, and perennial plantations grown on mineral soils have higher

Table 2

Profit in EUR per year for land use and soil class combinations in Usma, Zalenieki and Liezere parishes

\begin{tabular}{|l|c|c|c|c|c|c|}
\hline \multirow{2}{*}{ Land use } & \multicolumn{2}{c|}{ Usma parish } & \multicolumn{2}{c|}{ Zalenieki parish } & \multicolumn{2}{c|}{ Liezere parish } \\
\cline { 2 - 7 } & Mineral soil & $\begin{array}{c}\text { Organic } \\
\text { soil }\end{array}$ & Mineral soil & $\begin{array}{c}\text { Organic } \\
\text { soil }\end{array}$ & $\begin{array}{c}\text { Mineral soil } \\
\text { Organic } \\
\text { soil }\end{array}$ \\
\hline GOP & 9,170 & 141 & $\mathbf{5 2 5 , 9 8 0}$ & 2 & 34,300 & 1,002 \\
\hline Vegetables & 8,700 & 0 & $\mathbf{1 1 6 , 0 0 0}$ & 0 & 1,450 & 0 \\
\hline Perennial plantations & 2,900 & 0 & $\mathbf{7 5 , 4 0 0}$ & 0 & 37,700 & 0 \\
\hline Other crops & 51,600 & 3,600 & 229,800 & 0 & $\mathbf{3 3 3 , 0 0 0}$ & 27,600 \\
\hline No crops & 0 & 0 & 0 & 0 & 0 & 0 \\
\hline Grassland & 37,100 & 3,780 & 5,400 & 70 & $\mathbf{2 1 4 , 7 0 0}$ & 20,090 \\
\hline Not cultivated agricultural land & 0 & 0 & 0 & 0 & 0 & 0 \\
\hline Overgrown agricultural land & 0 & 0 & 0 & 0 & 0 & 0 \\
\hline Managed coniferous forest & $\mathbf{1 , 9 7 5 , 0 5 0}$ & 157,586 & 149,037 & 2,705 & 990,036 & 77,305 \\
\hline Managed deciduous forest & 169,980 & 46,242 & 135,270 & 6,881 & $\mathbf{1 , 0 5 0 , 0 0 0}$ & 81,324 \\
\hline Natural coniferous forest & $\mathbf{1 6 0 , 2 7 2}$ & 19,485 & 8,600 & 0 & 1,161 & 0 \\
\hline Natural deciduous forest & $\mathbf{1 9 , 3 5 0}$ & 3,038 & 133 & 7 & 0 & 0 \\
\hline
\end{tabular}

Source: authors' calculations based on Nipers, (2019) and Valujeva et al., (in preparation). 


\section{Working hours EUR per year for land use and soil class combinations in Usma, Zalenieki and Liezere parishes}

\begin{tabular}{|l|c|c|c|c|c|c|}
\hline \multirow{2}{*}{ Land use } & \multicolumn{2}{c|}{ Usma parish } & \multicolumn{2}{c|}{ Zalenieki parish } & \multicolumn{2}{c|}{ Liezere parish } \\
\cline { 2 - 7 } & Mineral soil & $\begin{array}{c}\text { Organic } \\
\text { soil }\end{array}$ & Mineral soil & $\begin{array}{c}\text { Organic } \\
\text { soil }\end{array}$ & $\begin{array}{c}\text { Mineral soil } \\
\text { Organic } \\
\text { soil }\end{array}$ \\
\hline GOP & 3,275 & 235 & $\mathbf{1 8 7 , 8 5 0}$ & 3 & 12,250 & 1,670 \\
\hline Vegetables & 3,000 & 0 & $\mathbf{4 0 , 0 0 0}$ & 0 & 500 & 0 \\
\hline Perennial plantations & 600 & 0 & $\mathbf{1 5 , 6 0 0}$ & 0 & 7,800 & 0 \\
\hline Other crops & 26,660 & 2,790 & 118,730 & 0 & $\mathbf{1 7 2 , 0 5 0}$ & 21,390 \\
\hline No crops & 0 & 0 & 0 & 0 & 0 & 0 \\
\hline Grassland & 11,130 & 1,620 & 1,620 & 30 & $\mathbf{6 4 , 4 1 0}$ & 8,610 \\
\hline Not cultivated agricultural land & 0 & 0 & 0 & 0 & 0 & 0 \\
\hline Overgrown agricultural land & 0 & 0 & 0 & 0 & 0 & 0 \\
\hline Managed coniferous forest & $\mathbf{2 1 , 9 4 5}$ & 1,751 & 1,656 & 30 & 11,000 & 859 \\
\hline Managed deciduous forest & 3,400 & 925 & 2,705 & 138 & $\mathbf{2 1 , 0 0 0}$ & 1,626 \\
\hline Natural coniferous forest & $\mathbf{2 , 3 7 4}$ & 289 & 127 & 0 & 17 & 0 \\
\hline Natural deciduous forest & $\mathbf{5 1 6}$ & 81 & 53 & 0 & 8 & 0 \\
\hline
\end{tabular}

Source: authors' calculations based on Nipers, (2019) and Valujeva et al., (in preparation).

working hours in Zalenieki compared to Usma and Liezere. A managed coniferous forest, natural coniferous forest, and natural deciduous forest on mineral soils provide higher working hours in Usma parish, while other crops, grassland and managed deciduous forest provide higher working hours in Liezere. Higher working hours from areas on organic soils are observed in Liezere parish (EUR 34,155 per year): compared to Usma (EUR 7,690 per year) and Zalenieki (EUR 200 per year) (Table 3).

\section{Improvements in supply of primary productivity}

Firstly, not cultivated and overgrown agricultural land on mineral soils with soil quality points less than 25 on mineral soils are transferred to managed coniferous forests on mineral soils, because biomass production in intensively managed forests is on average $26 \%$ higher than in unmanaged forests (Karttunen et al., 2018) and higher potential for biomass production is shown by coniferous stands (Nord-Larsen and Pretzsch, 2017). Secondly, not cultivated and overgrown agricultural land on organic soils is transferred to managed coniferous forests on organic soils, because afforestation of well-drained organic soils increases biomass production (Weslien et al., 2009), also this measure increases carbon sequestration in the soil, which is another soil function which we expect from our soils although we are not investigating that in this study. Thirdly, not cultivated and overgrown agricultural land on mineral soils with soil quality points in the range from 25 to 38 are transferred to grassland. Fourthly, not cultivated and overgrown agricultural land with soil quality points in the range from 38 to 77 on mineral soils is equally distributed between GOP, vegetables, perennial plantations, and other crops on mineral soils.

After applying land use changes to areas on mineral soils, the increase in profit is $5.6 \%$. A higher increase in profit is observed in Liezere parish (7.1\%), while lower increase in profit is in Zalenieki parish $(2.2 \%)$, but the increase in Usma parish is $5.6 \%$ (Figure 2). An increase in the supply of primary productivity function on organic soils is on average $4.0 \%$. A higher increase is observed in Liezere (5.2\%), but a lower increase is observed in Usma (3.0\%). In Zalenieki, there are no not cultivated or overgrown agricultural land on organic soils. A higher increase in working hours after land use changes on mineral soils is in Usma (36.6\%) and Liezere (7.6\%), but in Zalenieki the increase is only $2.0 \%$ (Figure 2). An increase in working hours after land use changes on organic soils from not cultivated and overgrown to managed forests is in the range from $0.4 \%$ in Liezere to $1.0 \%$ in Usma.

Food and fibre is not the only social demand for our land that we expect. We also expect carbon storage and regulation, nutrient cycling, water purification and provision of habitat for biodiversity (Schulte et al., 2014). Therefore, before applying land use changes or changes in management practices we have to consider other soil function and national commitments. Climate-smart land management is a key to achieve socio-economic and environmental targets; therefore, further research is necessary to explore how these land use changes affect other soil functions, namely climate function and biodiversity. 


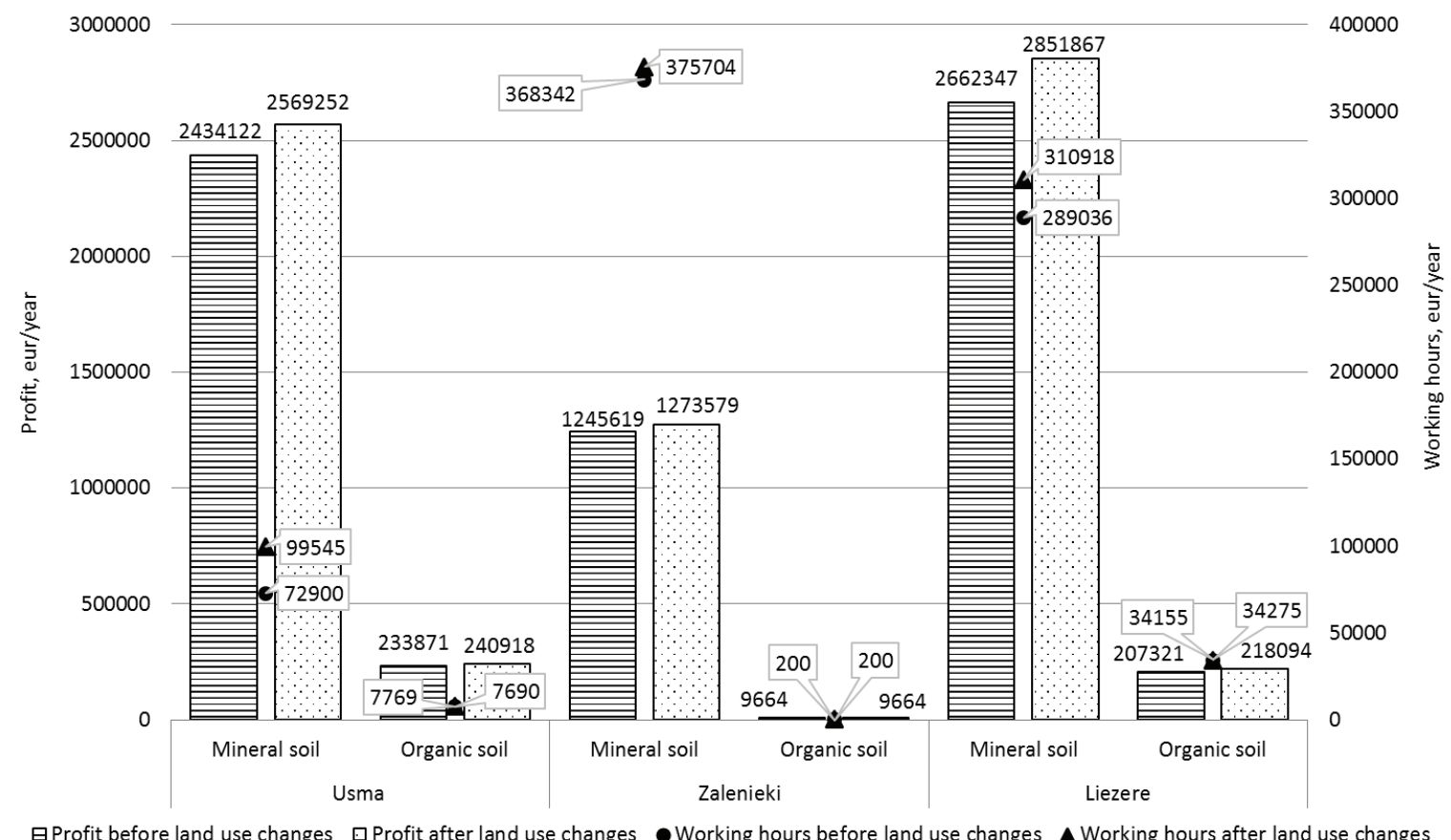

Figure 2. Profit and working hours before and after applying land use changes in Usma, Zalenieki and Liezere parishes.

Source: authors' construction.

\section{Conclusions}

Soil is non-renewable resource and provides food and biomass production for society. Also, it provides many other ecological and social functions like water purification, habitat for biodiversity, nutrient cycling, and carbon sequestration and regulation. Therefore, protection of soils and the preservation of its capacity to perform socio-economic and ecological functions is necessary.

Land use changes affect all soil functions that we expect from our land, especially primary productivity function. Higher profit and working hours are observed from areas on mineral soils. Short-term benefits are received from agricultural land, while forest land provides a long-term return which increases over time but can only be obtained after a reaching the age of felling. Before applying land use changes or changes in management practices we have to consider other soil function and national commitments.

\section{Acknowledgements}

The research is supported by 'Strengthening Research Capacity in the Latvia University of Life Sciences and Technologies' (Z26).

\section{References}

1. Blum, W.E.H. (1993). Soil Protection Concept of the Council of Europe and Integrated Soil Research, in: Eijsackers H.J.P., Hamer T. (Eds.), Integrated Soil and Sediment Research: A basis for Proper Protection, Soil and Environment, Dordrecht: Kluwer Academic Publishers, Vol. 1, pp. 37-47.

2. Coyle, C., Creamer, R.E., Schulte, R.P.O., O'Sullivan, L., \& Jordan, P. (2016). A Functional Land Management conceptual framework under soil drainage and land use scenarios. Environ. Sci. Policy 56, 39-48. DOI: 10.1016/J.ENVSCI.2015.10.012.

3. EC (2016). Commission staff working document impact assessment accompanying the document proposal for a regulation of the European Parliament and of the council on binding annual greenhouse gas emission reductions by Member States from 2021 to 2030 for a resilient Energy Union and to meet commitments under the Paris Agreement and amending Regulation No 525/2013 of the European Parliament and the Council on a mechanism for monitoring and reporting greenhouse gas emissions and other information relevant to climate change, SWD/2016/0247 final - 2016/0231 (COD).

4. Greiner, L., Nussbaum, M., Papritz, A., Fraefel, M., Zimmermann, S., Schwab, P., Grêt-Regamey, A., \& Keller, A. (2018). Assessment of soil multi-functionality to support the sustainable use of soil resources on the Swiss Plateau. Geoderma Reg. 14, DOI: 10.1016/J.GEODRS.2018.E00181.

5. Karttunen, K., Ahtikoski, A., Kujala, S., Törmä, H., Kinnunen, J., Salminen, H., Huuskonen, S., Kojola, S., Lehtonen, M., Hynynen, J., \& Ranta, T. (2018). Regional socio-economic impacts of 
intensive forest management, a CGE approach. Biomass and Bioenergy 118, 8-15. DOI: 10.1016/J. BIOMBIOE.2018.07.024.

6. Latvijas Bioekonomikas stratēǵija 2030 (LIBRA2030) 2017 (Latvian Bioeconomy Strategy until 2030). Latvijas Lauksaimniecības universitāte. (in Latvian)

7. Mueller, L., Schindler, U., Mirschel, W., Shepherd, T.G., Ball, B.C., Helming, K., Rogasik, J., Eulenstein, F., \& Wiggering, H. (2010). Assessing the productivity function of soils. A review. Agron. Sustain. Dev. 30, 601-614. DOI: 10.1051/agro/2009057.

8. Nipers, A. (2019). Zemes izmantošanas optimizācijas iespēju novērtējums Latvijas klimata politikas kontekstā (Evaluation of the Land Use Optimization Opportunities within the Latvian Climate Policy Framework). Jelgava: Latvija. Latvijas Lauksaimniecības universitāte. (in Latvian)

9. Latvia's National Inventory Report 1990-2016 (NIR) (2018). Submission under UNFCCC and the Kyoto Protocol.

10. Nord-Larsen, T., \& Pretzsch, H. (2017). Biomass production dynamics for common forest tree species in Denmark - Evaluation of a common garden experiment after 50 yrs of measurements. For. Ecol. Manage. 400, 645-654. DOI: 10.1016/J.FORECO.2017.06.035.

11. Schulte, R.P.O., Creamer, R.E., Donnellan, T., Farrelly, N., Fealy, R., O’Donoghue, C., \& O’hUallachain, D. (2014). Functional land management: A framework for managing soil-based ecosystem services for the sustainable intensification of agriculture. Environ. Sci. Policy 38, 45-58. DOI: 10.1016/J. ENVSCI.2013.10.002.

12. State Regional Development Agency (SRDA) (2016). Reǵionālās attīstības indikatoru modulis Raim.gov. lv. (Regional Development Indicator Module RDIM.gov.lv) Retrieved February 12, 2019, from https:// raim.gov.lv/lv/node/39. (in Latvian)

13. UN (2017). United Nations, Department of Economic and Social Affairs, Population Division, World Population Prospects: The 2017 Revision, Key Findings and Advance Tables. Working Paper No. ESA/P/ $\mathrm{WP} / 248$.

14. Valujeva, K., Nipers., A., Lupikis., A., \& Schulte, R.P.O. (in preperation). Identifying regional opportunities for meeting national obligations on sustainable land management: an example from bioeconomy.

15. Valujeva, K., O’Sullivan, L., Gutzler, C., Fealy, R., \& Schulte, R.P.O. (2016). The challenge of managing soil functions at multiple scales: An optimisation study of the synergistic and antagonistic trade-offs between soil functions in Ireland. Land use policy 58, 335-347. DOI: 10.1016/J.LANDUSEPOL.2016.07.028.

16. Weslien, P., Kasimir Klemedtsson, Å., Börjesson, G., \& Klemedtsson, L. (2009). Strong pH influence on $\mathrm{N} 2 \mathrm{O}$ and CH4 fluxes from forested organic soils. Eur. J. Soil Sci. 60, 311-320. DOI: 10.1111/j.13652389.2009.01123.x. 